\title{
PENINGKATAN HASIL BELAJAR MATEMATIKA MELALUI MODEL PEMBELAJARAN PROBLEM SOLVING PADA SISWA KELAS V SDN KAKATUA KECAMATAN MARISOKOTA MAKASSAR
}

\author{
Hamzah Pagarra \\ Prodi PGSD Fakultas Ilmu Pendidikan Universitas Negeri Makassar \\ hamzah.pagarra@gmail.com
}

\begin{abstract}
ABSTRAK
Permasalahan penelitian ini adalah rendahnya hasil belajar siswa pada mata pelajaran matematika kelas Va. Adapun rumusan masalah dalam penelitian ini adalah bagaimana peningkatan hasil belajar matematika melalui model pembelajaran problem solving pada siswa kelas V SDN Kakatua Makassar. Tujuan penelitian ini Untuk mengetahui peningkatan hasil belajar matematika melalui model pembelajaran problem solving pada siswa kelas V SDN Kakatua Makassar. Pendekatan yang digunakan adalah deskriptif kualitatif dengan jenis penelitian adalah Penelitian Tindakan Kelas (PTK) yang bersiklus yaitu meliputi perencanaan, pelaksanaan, observasi, dan refleksi.Fokus penelitian ini adalah penerapan model pembelajaranproblem solving dan hasil belajar.Setting penelitian ini adalah SDN Kakatua Makassar, yang bertempat di Jalan Kakatua Kecamatan Mariso Kota Makassar. Subjek penelitian adalah guru dan siswa kelas V dengan jumlah siswa 28 orang.Teknik pengumpulan data yang digunakan adalah observasi, tes dan dokumentasi.Analisis data yang digunakan adalah kualitatif deskriptif.Hasil penelitian menunjukkanpada siklus I aktivitas mengajar guru berada pada kategori cukup mengalami peningkatan di siklus II menjadi kategori baik.Demikian pula aktivitas belajar siswa pada sisklus I berada pada kategori cukup mengalami peningkatan di siklus II menjadi kategori baik.Peningkatan juga terjadi pada hasil belajar siswa.Pada siklus I belum berhasil mencapai ketuntasan klasikal yang telah ditentukan dan berada pada kategori cukup.Pada siklus II hasil belajar siswa sudah meningkat, hal itu dilihat dari nilai rata-rata yang mengalami peningkatan dan berada pada kategoribaik.Kesimpulan penelitian ini yaitu Model Pembelajaran Problem Solving dapat meningkatkan hasil belajar siswa kelas V SDN Kakatua Kecamatan Mariso Kota Makassar.
\end{abstract}

Kata Kunci: Problem Solving, Hasil Belajar

\section{PENDAHULUAN}

Pendidikan merupakan suatu upaya untuk mewujudkan sumber daya manusia yang berkualitas. Untuk mencapai hal ini, diperlukan suatu pendukung yaitu kiat dalam meningkatkan mutu pendidikan. Pendidikan juga dikatakan sebagai proses pembentukan pribadi. Seperti yang dikatakan Tirtarahardja, dkk (2008: 34)"sebagai proses pembentukan pribadi, pendidikan diartikan sebagai suatu kegiatan yang sistematis dan sistemik terarah kepada terbentuknya kepribadian peserta didik".

Matematika berbeda dengan ilmu lain. Materi matematika bersifat hierarkis. Dalam mempelajarinya harus bersifat kontinu, rajin latihan dan disiplin. Apabila sejak awal siswa sudah tidak senang dengan pelajaran matematika maka siswa akan mengalami kesulitan pada materi pelajaran selanjutnya. Tidak sedikit juga orang yang memandang matematika sebagai bidang studi yang sulit. Meskipun demikian orang harus mempelajarinya karena merupakan sarana untuk memecahkan masalah dalam kehidupan sehari-hari. Salah satu tujuan mempelajari matematika adalah membentuk kepribadian dalam diri siswa untuk menggunakan matematika dalam kehidupan sehari-hari.

Matematika dipandang sebagai mata pelajaran yang memegang peranan penting dalam berbagai disiplin dan memajukan daya pikir manusia. Karena dengan belajar matematika, siswa akan belajar bernalar secara kritis, kreatif, dan aktif. Menurut Jacobsin, dkk (Susanto, 2014: 189) "agar kemampuan komunikasi matematika siswa dapat berkembang, kemampuan pemahaman matematika siswa juga perlu ditingkatkan".

Berdasarkan hasil observasi di kelas Va SDN Kakatua Kecamatan Mariso Kota Makassar, menunjukkan bahwa hasil belajar 
siswa pada mata pelajaran matematika masih rendah. Adapun hasil dari pretest yang dilakukan oleh peneliti, hasil pembelajaran matematika yang diperoleh dari 28 jumlah siswa yang terdiri dari 16 siswa laki-laki dan 12 siswa perempuan, hanya 8 orang atau $28 \%$ yang mendapat nilai di atas nilai KKM (Kriteria Ketuntasan Minimal) yang ditetapkan 70 dan dinyatakan lulus. Hal ini disebabkan oleh dua aspek yaitu aspek guru dan aspek siswa. Dari aspek guru, yakni: 1) guru kurang melatih siswa untuk menghadapi dan memecahkan masalah secara realistis, dan 2) guru kurang mengarahkan siswa untuk mengidentifikasi dan melakukan penyelidikan, sedangkan dari aspek siswa, yakni: 1) siswa kurang dilatih untuk memecahkan masalahnya, dan 2) siswa kurang menghayati kehidupan sehari-hari sehingga menimbulkan kepasifan siswa dalam menerima pelajaran matematika.

Berdasarkan beberapa faktor diatas menunjukkan bahwa pembelajaran matematika perlu diperbaiki guna meningkatkan pemahaman siswa terhadap konsep-konsep matematika. Mengingat pentingnya matematika maka diperlukan pembenahan proses pembelajaran yang dilakukan guru yaitu dengan menerapkan suatu model pembelajaran yang dapat meningkatkan pemahaman siswa terhadap konsep-konsep matematika. Salah satu cara untuk mengatasi yaitu dengan menerapkan model pemecahan masalah (problem solving) dalam pembelajaran.

Pemecahan masalah (problem solving) adalah proses yang ditempuh seseorang untuk menyelesaikan masalah yang dihadapinya sampai masalah itu tidak lagi menjadi masalah baginya. Model problem solving sangat potensial untuk melatih siswa berfikir kreatif dalam menghadapi berbagai masalah baik itu masalah pribadi maupun masalah kelompok untuk dipecahkan sendiri-sendiri atau secara bersama-sama. Siswa belajar sendiri untuk mengidentifikasi penyebab masalah dan alternatif untuk memecahkan masalahnya.

Penerapan model pemecahan masalah (problem solving) pada pembelajaran matematika, merupakan salah satu upaya yang tepat dilakukan oleh guru karena dengan menerapkan model ini dapat memberikan siswa kesempatan seluas-luasnya untuk memecahkan masalah matematika dengan strateginya sendiri.Untuk memperbaiki hasil belajar, harus dimulai dengan memperbaiki prosesnya. Proses yang baik biasanya akan memberikan hasil yang baik pula. Proses yang dimaksud adalah kegiatan belajar mengajar pada mata pelajaran matematika. Berdasarkan hasil penelitian yang dilakukan oleh Akbar (2015: 62), menunjukkan bahwa "penerapan model pemecahan masalah (problem solving) pada pelajaran matematika dalam bentuk soal cerita dapat meningkatkan hasil belajar siswa di kelas V SDN 17 Pare-pare".Berdasarkan uraian dalam latar belakang, maka rumusan masalah dalam penelitian ini adalah "Bagaimanakah peningkatan hasil belajar matematika melaluipenerapan model pembelajaran problem solving pada siswa kelas V SDN Kakatua Makassar?"

Belajar merupakan komponen ilmu pendidikan yang berkenaan dengan tujuan dan bahan acuan interaksi, baik yang bersifat eksplisit maupun implisit (tersembunyi). Menurut Faturrahman, dkk (2012: 6) untuk menangkap isi dan pesan belajar, maka dalam belajar tersebut individu menggunakan kemampuan pada ranah-ranah:

1) Kognitif yaitu kemampuan yang berkenaan dengan pengetahuan, penalaran atau pikiran yang terdiri dari kategori pengetahuan, pemahaman, penerapan, analisis, sisntesis, dan evaluasi

2) Afektif yaitu kemampuan yang mengutamakan perasaan, emosi, dan reaksireaksi yang berbeda dengan penalaran yang terdiri dari kategori penerimaan, partisipasi, penilaian sikap, organisasi dan pembentukan pola hidup

3) Psikomotorik yaitu kemampuan yang mengutamakan keterampilan jasmani yang terdiri dari persepsi, kesiapan gerakan terbimbing, gerakan terbiasa, gerakan kompleks, penyesuaian pola gerak dan kreativitas.

Menurut Gagne "belajar adalah perubahan disposisi atau kemampuan yang dicapai seseorang melalui kativitas. Perubahan disposisi tersebut diperoleh langsung dari proses pertumbuhan seseorang secara alamiah". (Suprijono, 2012:2)

Sedangkan menurut Riyanto (2009: 6) belajar adalah suatu proses untuk mengubah performansi yang tidak terbatas pada keterampilan, tetapi juga meliputi fungsifungsi, seperti skill, persepsi, emosi, proses berfikir, sehingga dapat menghasilkan perbaikan performansi.

Berdasarkan pendapat para ahli di atas dapat disimpulkan bahwa belajar adalah suatu proses yang dilakukan oleh seseorang untuk mengetahui apa yang baik dan yang buruk 
serta dapat memilih apa yang dilakukannya dengan penuh tanggung jawab dan mengubah perilaku yang bersifat permanen sebagai hasil dari pengalaman.

\section{Pengertian hasil belajar}

Bukti bahwa seseorang telah belajar ialah terjadinya perubahan tingkah laku pada orang tersebut, misalnya dari tidak tahu menjadi tahu dan dari tidak mengerti menjadi mengerti. Selain itu, sasaran sebenarnya dari kegiatan belajar mengajar adalah hasil belajar. Apabila hasil belajar mengajar berjalan dengan baik, maka hasil belajar juga baik. Hasil belajar adalah prestasi yang dicapai oleh siswa setelah mengikuti proses belajar mengajar yang berkenaan dengan materi suatu mata pelajaran.

Menurut Nawawi (Susanto, 2014: 5) bahwa "hasil belajar dapat diartikan sebagai tingkat keberhasilan siswa dalam mempelajari materi pelajaran di sekolah yang dinyatakan dalam skor yang diperoleh dari hasil tes mengenal sejumlah materi pelajaran tertentu".

Sedangkan Suprijono (2012: 5) mengemukakan bahwa "hasil belajar adalah perubahan perilaku secara keseluruhan bukan hanya salah satu aspek potensi kemanusiaan saja". Hasil belajar mempunyai peranan penting dalam proses pembelajaran. Proses penilaian terhadap hasil belajar dapat memberikan informasi kepada guru tentang kemajuan siswa dalam upaya mencapai tujuantujuan belajarnya melalui kegiatan belajar. Selanjutnya dari informasi tersebut guru dapat menyusun dan membina kegiatan-kegiatan siswa lebih lanjut.

Berdasarkan beberapa pernyataan diatas, dapat disimpulkan bahwa seseorang telah dikatakan belajar jika seseorang tersebut telah mengalami suatu proses kegiatan tertentu sehingga terjadi suatu perubahan tingkah laku yang keliatan dan nampak. Perubahan inilah yang dinamakan dengan hasil belajar.

Berdasarkan pendapat di atas, maka dapat disimpulkan bahwa faktor-faktor yang mempengaruhi hasil belajar adalah faktor internal dan faktor eksternal, dimana faktor internal adalah fisiologis dan psikologis sedangkan faktor eksternal adalah lingkungan dan instrumental.

\section{Pembelajaran Matematika di Sekolah Dasar}

Matematika merupakan salah satu mata pelajaran umum yang di ajarkan mulai dari jenjang sekolah dasar sampai perguruan tinggi. Pemusatan pengajaran matematika di SD sering hanya pada keterampilan berhitung (penjumlahan, pengurangan, perkalian, pembagian bilangan bulat, pecahan dan desimal) dan beranggapan bahwa jika anak telah menguasai berhitung ia telah menguasai semua kompetensi matematika.

Matematika sebagai studi tentang objek abstrak tentu saja sangat sulit untuk dapat dipahami oleh siswa-siswa SD yang belum mampu berpikir formal. Sebab orientasinya masih terkait dengan benda-benda konkret. Ini tidak berarti bahwa matematika tidak mungkin tidak diajarkan di jenjang pendidikan dasar, bahkan pada hakekatnya matematika lebih baik diajarkan pada usia dini.

Mengingat pentingnya matematika untuk siswa-siswa usia dini di SD, perlu dicari suatu cara mengelola proses belajar-mengajar di SD sehingga matematika dapat dicerna oleh siswasiswa SD. Disamping itu, matematika juga harus bermanfaat dan relevan dengan kehidupannya, karena itu pembelajaran matematika di jenjang pendidikan dasar harus ditekankan pada penguasaan keterampilan dasar dari matematika itu sendiri. Keterampilan yang menonjol adalah keterampilan terhadap penguasaan operasioperasi hitung dasar (penjumlahan, pengurangan, perkalian dan pembagian).

Untuk itu dalam pembelajaran matematika terdapat dua aspek yang perlu diperhatikan, yaitu: (1) matematika sebagai alat untuk menyelesaikan masalah, dan (2) matematika merupakan sekumpulan keterampilan yang harus dipelajari. Keterampilan yang cukup membuat siswa mempunyai kesempatan mengorganisasikan konsep yang sudah dicerna. Konsep yang sudah diterima dengan baik dalam benak siswa akan memudahkan pemahaman konsep-konsep berikutnya. Untuk itu dalam penyajian topiktopik baru hendaknya dimulai pada tahapan yang paling sederhana ketahapan yang lebih kompleks, dari yang konkret menuju ke yang abstrak, dari lingkungan dekat anak ke lingkungan yang lebih luas.

Dari tujuan pengajaran matematika sekolah tersebut dapat di asumsikan bahwa aspek penting yang terkandung didalam pengajaran matematika adalah memberikan penekanan pada penataan nalar dan pembentukan sikap siswa, serta memberikan penekanan dalam penerapan matematika, baik dalam kehidupan sehari - hari maupun dalam membantu mempelajari ilmu pengetahuan lainnya. 


\section{Model Pembelajaran Pemecahan Masalah (problem solving)}

Model pembelajaran merupakan petunjuk bagi guru dalam merencanakan pembelajaran di kelas, mulai dari mempersiapkan perangkat pembelajaran, media dan alat bantu, sampai alat evaluasi yang mengarah pada upaya pencapaian tujuan pelajaran.

Model pembelajaran pemecahan masalah (problem solving) bukan hanya sekedar model mengajar, tetapi juga merupakan suatu model berfikir, sebab dalam problem solving dapat menggunakan model-model lainnya yang dimulai dengan mencari data sampai kepada menarik kesimpulan. Model ini memberikan kesempatan siswa belajar sendiri untuk mengidentifikasi penyebab masalah dan alternatif untuk memecahkan masalahnya. Tugas guru dalam model pembelajaran pemecahan masalah(problem solving) adalah memberikan kasus atau masalah kepada siswa untuk dipecahkan.

"Model Problem Solving (PS) adalah suatu model pembelajaran yang melakukan pemusatan pada pembelajaran dan keterampilan pemecahan masalah, yang diikuti dengan penguatan keterampilan" (Hamzah, 2014). Ketika dihadapkan dengan suatu pertanyaan, siswa dapat melakukan pemecahan masalah untuk memilih dan mengembangkan tanggapannya.

Dari beberapa pernyataan tersebut, peneliti menyimpulkan bahwa model pembelajaran pemecahan masalah (problem solving) sebagai rangkaian tindakan yang tepat digunakan untuk mencapai tujuan. Untuk memperoleh kemampuan dalam pemecahan masalah, seseorang harus memiliki banyak pengalaman dalam memecahkan berbagai masalah. Berbagai hasil penelitian menunjukkan bahwa siswa yang banyak diberi latihan pemecahan masalah (problem solving) memiliki nilai lebih tinggi dalam tes pemecahan masalah (problem solving) dibandingkan siswa yang lebih sedikit latihannya.

\section{Langkah-langkah model pembelajaran pemecahan masalah (problem solving)}

Dalam proses pembelajaran, di samping perlunya penalaran yang baik, juga penting menguasai langkah-langkah memecahkan masalah secara tepat. Belajar memecahkan masalah itu berlangsung jika siswa menyadari masalah bila ia dihadapkan kepada situasi keraguan dan kekaburan sehingga merasakan adanya semacam kesulitan.

Menurut Deb Russell (Huda, 2014: 274) bahwa ada 4 sintak dari Problem solving, yaitu:Tahap 1: Clues, Tahap 2: Game Plan, Tahap 3: Solve dan Tahap 4: Reflect

\section{Model pembelajaran pemecahan masalah (problem solving) dalam pembelajaran matematika}

Pemecahan masalah (problem solving) merupakan komponen yang sangat penting dalam matematika. Secara umum dijelaskan bahwa pemecahan masalah (problem solving) adalah proses menerapkan suatu pengetahuan yang telah diperoleh siswa ke dalam situasi yang baru. Selain itu, pemecahan masalah (problem solving) merupakan aktivitas yang sangat penting dalam pembelajaran matematika dimana tujuan belajar yang ingin dicapai dalam pemecahan masalah (problem solving) berkaitan dengan kehidupan seharihari. Dengan pemecahan masalah (problem solving) matematika ini, siswa melakukan kegiatan yang dapat mendorong berkembangnya pemahaman dan penghayatan terhadap prinsip, nilai, dan proses matematika.

Dalam pengajaran matematika, pemecahan masalah berarti serangkaian operasi mental yang dilakukan seseorang untuk mencapai suatu tujuan tertentu. Pemecahan masalah matematika menyangkut pemecahan masalah matematika disekolah maupun di luar sekolah.

Susanto (2014) menyimpulkan bahwa pemecahan masalah (problem solving) dapat dikelompokkan ke dalam tiga bagian dilihat dari aspek kegunaan atau fungsinya, yaitu 1) pemecahan masalah (problem solving) sebagai tujuan, 2) pemecahan masalah (problem solving) sebagai proses, dan 3) pemecahan masalah (problem solving) sebagai keterampilan dasar. Dilihat dari Kurikulum Tingkat Satuan Pendidikan (KTSP) bahwa ada seluruh komponen telah dijabarkan dengan jelas bahwa pembelajaran yang digunakan pada matematika adalah model pemecahan masalah (problem solving). Pemecahan masalah (problem solving) merupakan bagian dari kurikulum matematika yang sangat penting karena dalam proses pembelajaran maupun penyelesaian, siswa dimungkinkan memperoleh pengalaman menggunakan kemampuan dan keterampilan yang sudah dimiliki untuk diterapkan dalam pemecahan 
masalah (problem solving) yang bersifat tidak rutin.

Dengan demikian, dapat disimpulkan bahwa dengan menerapkan model pemecahan masalah (problem solving) diharapkan dapat menimbulkan minat sekaligus kreativitas dan motivasi dalam mempelajari matematika serta siswa dapat memperoleh pengalaman langsung dalam mempelajari matematika yang bisa dikaitkan dengan kehidupan sehari-harinya. Sehingga siswa dapat memperoleh manfaat dari apa yang dipelajarinya dan dapat dikembangkan dalam kehidupan nyata, baik dari proses maupun hasil belajarnya.

\section{METODE PENELITIAN}

Pendekatan yang digunakan dalam penelitian ini adalah pendekatan deskriptif kualitatif. Pendekatan ini dipilih untuk mendeskripsikan aktivitas mengajar guru dan aktivitas belajar guru dalam pelaksanaan tindakan pembelajaran.

Adapun jenis penelitian yang digunakan yaitu Penelitian Tindakan Kelas (PTK) yang bersifat deskriptif. Menurut Kunandar (2012: 45) bahwa: "PTK adalah penelitian tindakan yang dilakukan dengan tujuam memperbaiki mutu praktik pembelajaran di kelas".

Penelitian ini dilaksanakan di SDN Kakatua Makassar, yang bertempat di Jalan Kakatua Kecamatan Mariso Kota Makassar. Pelaksanaan penelitian ini direncanakan pada semester I (ganjil tahun pelajaran 2016/2017. Subjek dari penelitian ini adalah guru dan siswa kelas Va SDN Kakatua Makassar. Adapun jumlah siswa 28 orang yang terdiri dari 16 siswa laki-laki dan 14 siswa perempuan. Alasan memilih kelas Va sebagai subjek penelitian karena masih ada siswa yang mengalami kesulitan belajar matematika.

Adapun teknik pengumpulan data yang

digunakan dalam penelitian ini adalah:

1. Pengamatan (observasi)

2. Tes

3. Dokumentasi

Untuk mendukung hasil penelitian dan penilaian, perlu dilakukan analisis data. Analisis data dalam penelitian ini dilakukan selama dan sesudah pengumpulan data. Analisis data dilakukan dengan membandingkan hasil tes, observasi, pada tahap refleksi dari siklus penelitian. Data hasil observasi dianalisis secara kualitatif sedangkan kemampuan belajar siswa berupa pemberian tes, dianalisis secara kuantitatif dengan menggunakan analisis data deskriptif yang terdiri dari 3 tahap kegiatan yang dilakukan secara berurutan yaitu 1) mereduksi data, 2) menyajikan data, dan 3) menarik kesimpulan (Kunandar, 2012: 102)

\section{HASIL \& PEMBAHASAN}

\section{A. Hasil Penelitian}

Hasil penelitian ini terdiri dari data aktivitas mengajar guru dan aktivitas belajar siswa serta data hasil tes akhir di setiap siklus. Adapun pelaksanaannya dengan menerapkan model pembelajaran pemecahan masalah (problem solving) dalam pembelajaran matematika dengan materi pada siklus I bangun datar dan pada siklus II bangun ruang di kelas V SDN Kakatua Kecamatan Mariso Kota Makassar. Padapelaksanaan pembelajaran, peneliti bertindak sebagai observer dan wali kelas V SDN Kakatua Kecamatan Mariso Kota Makassar sebagai guru. Tahap-tahap dalam pembelajaran setiap pelaksanaan disesuaikan dengan tahap-tahap pembelajaran yang berdasarkan model pembelajaran pemecahan masalah (problem solving), yaitu:(1) Memahami masalah sesuai dengan petunjuk (clue) yang diberikan; (2) Membuat rencana pemecahan masalah untuk memecahkan masalah; (3) Melaksanakan strategi pemecahan masalah (solve); (4) Memeriksa kembali penyelesaian yang telah dilaksanakan (reflect).

Deskripsi pembelajaran untuk keefektifan model pembelajaran pemecahan masalah (problem solving) dalam meningkatkan hasil belajar siswa dengan materi bangun datar dan bangun ruang disajikan sebanyak dua siklus dan setiap siklus terdiri dari dua kali pertemuan. Data setiap pelaksanaan dipaparkan secara terpisah. Adapun paparan data penelitian mencakup: (1) Paparan data sebelum Pelaksanaan; (2) Paparan data siklus I dan (3) Paparan data siklus II. Hal ini bertujuan untuk melihat perkembangan alur setiap siklus. Adapun perincian paparan data adalah sebagai berikut:

\section{Paparan Data Hasil Siklus I}

Pelaksanaan siklus I dimulai pada tanggal 06September 2016 dan 13September 2016 dengan materi bangun datar segitiga dan materi bangun datar persegi dalam bentuk soal cerita yang tahapan pelaksanaannya meliputi perencanaan, pelaksanaan, observasi dan refleksi. Masing-masing tahapan diuraikan sebagai berikut: 


\section{1) Hasil observasi aktivitas mengajar guru}

Lembar observasi kegiatan mengajar guru digunakan untuk mengetahui aktivitas mengajar guru pada pembelajaran matematika dengan menerapkan langkah-langkah model pembelajaran pemecahan masalah (problem solving). Pada setiap pertemuan observer mengamati dan memperhatikan guru dalam proses pembelajaran dengan menerapkan model pembelajaran pemecahan masalah (problem solving) yang teridiri dari 4 tahap yaitu: (a) Memahami masalah sesuai dengan petunjuk (clue) yang diberikan; (b) Membuat rencana pemecahan masalah untuk memecahkan masalah; (c) Melaksanakan strategi pemecahan masalah (solve); (d) Memeriksa kembali penyelesaian yang telah dilaksanakan (reflect).

Berdasarkan observasi terhadap kegiatan mengajar guru, diperoleh data bahwa pada pertemuan pertama dan keduaaspek memahami masalah sesuai dengan petunjuk (Clue) yang diberikan, dikategorikan baik karena ketiga indikator terlaksana yaitu guru menjelaskan materi tentang bangun datar segitiga dan bangun datar persegi, guru memberikan masalah dalam bentuk LKS tentang bangun datar segitiga dan bangun datar persegi dalam bentuk soal cerita, dan guru mempersilahkan siswa berdiskusi untuk menganalisis masalah tentang bangun datar segitiga dan bangun datar persegi dalam bentuk soal cerita yang terdapat dalam LKS.

Pada aspek membuat rencana pemecahan masalah untuk memecahkan masalah, pertemuan pertama dan pertemuan kedua dikategorikan cukup karena hanya dua indikator yang terlaksana yaitu guru membimbing siswa menyusun pertanyaan pada soal cerita tentang bangun datar segitiga dalam bentuk kalimat matematika dan guru membantu dan membimbing siswa saling bekerja sama dalam kelompok tapi indikator guru mendorong siswa untuk mengemukakan ide dalam kelompoknya tidak terlaksana. Pada aspek melaksanakan strategi pemecahan masalah (solve), pertemuan pertama dikategorikan kurang karena hanya satu indikator yang terlaksana yaitu gurumengarahkan siswa untuk menyelesaikan soal cerita tentang bangun datar segitiga sesuai langkah-langkah dalam pemecahan masalah (problem solving) tetapi dua indikator tidak terlaksana yaitu guru tidak membantu siswa dalam memaparkan hasil diskusi kelompoknya dan guru tidak meminta siswa untuk menuliskan hasil kerja kelompoknya di papan tulis dan kelompok lain memperhatikan, sedangkan pertemuan kedua dikategorikan cukup karena dua indikator terlaksana yaitu guru mengarahkan siswa untuk menyelesaikan soal cerita tentang bangun datar persegi sesuai langkah-langkah dalam pemecahan masalah (problem solving) dan guru membantu siswa dalam memaparkan hasil diskusi kelompoknya, tapi indikator guru meminta siswa untuk menuliskan hasil kerja kelompoknya di papan tulis dan kelompok lain memperhatikan tidak terlaksana. Pada aspek memeriksa kembali penyelesaian yang telah dilaksanakan (reflect), pertemuan pertama dan kedua dikategorikan kurang karena hanya satu indikator yang terlaksana yaitu gurumembantu siswa untuk melakukan refleksi tetapi indikator guru mendorong siswa untuk aktif memberikan tanggapan terhadap sajian hasil pemecahan masalah dalam bentuk soal cerita dan indikator guru memberikan saran terhadap sajian hasil pemecahan masalah dalam bentuk soal cerita oleh kelompok lain tidak terlaksana.

Berdasarkan data dari siklus I dapat disimpulkan bahwa pencapaian implementasi aktivitas belajar matematika materi bangun datar melalui penerapan model pembelajaran pemecahan masalah (problem solving) untuk aspek guru dikategorikan cukup. Untuk lebih jelasnya hasil observasi aktivitas mengajar guru dapat dilihat pada lampiran 4 halaman 79 dan lampiran 10 halaman 103.

\section{2) Hasil observasi aktivitas belajar siswa}

Lembar observasi kegiatan belajar siswa digunakan untuk mengetahui aktivitas belajar siswa pada pembelajaran matematika dengan menerapkan langkah-langkah model pembelajaran pemecahan masalah (problem solving). Pada setiap pertemuan observer mengamati dan memperhatikan siswa dalam proses pembelajaran dengan menerapkan model pembelajaran pemecahan masalah (problem solving) yang terdiri atas 4 tahap yaitu: (a) Memahami masalah sesuai dengan petunjuk (clue) yang diberikan; (b) Membuat rencana pemecahan masalah untuk memecahkan masalah; (c) Melaksanakan strategi pemecahan masalah (solve); (d) Memeriksa kembali penyelesaian yang telah dilaksanakan (reflect).

Berdasarkan observasi terhadap aktivitas belajar siswa, diperoleh data bahwa pada 
pertemuan pertama dan keduaaspek memahami masalah sesuai dengan petunjuk (clues) yang diberikan dikategorikan baik karena ketiga indikator terlaksana yaitu siswa mendengarkan penjelasan dari guru tentang materi bangun datar segitiga dan bangun datar persegi, siswa memahami masalah dalam bentuk LKS tentang bangun datar segitiga dan bangun datar persegi dalam bentuk soal cerita, dan siswa berdiskusi untuk menganalisis masalah tentang bangun datar segitiga dan bangun datar persegi dalam bentuk soal cerita yang terdapat dalam LKS. Pada aspek membuat rencana pemecahan masalah untuk memecahkan masalah, pertemuan pertama dan kedua dikategorikan cukup karena dua indikator yang terlaksana yaitu siswa menyusun pertanyaan pada soal cerita dalam bentuk kalimat matematika dan siswa saling bekerja sama dalam kelompok tetapi indikator siswamengemukakan ide dalam kelompoknya tidak terlaksana.

Pada aspek melaksanakan strategi pemecahan masalah (solve), pertemuan pertama dikategorikan kurang karena hanya satu indikator yang terlaksana yaitu siswa mampu menyelesaikan soal cerita tentang bangun datar segitiga sesuai langkah-langkah dalam pemecahan masalah (problem solving) tetapi indikator siswamemaparkan hasil diskusi kelompoknya dan siswa menuliskan hasil kerja kelompoknya di papan tulis dan kelompok lain memperhatikan tidak terlaksana, sedangkan pertemuan kedua dikategorikan cukup karena dua indikator yang terlaksana yaitu siswa mampu menyelesaikan soal cerita tentang bangun datar persegi sesuai langkah-langkah dalam pemecahan masalah (problem solving) dan siswa memaparkan hasil diskusi kelompoknya tetapi indikator siswa menuliskan hasil kerja kelompoknya di papan tulis dan kelompok lain memperhatikan tidak terlaksana.
Pada aspek memeriksa kembali penyelesaian yang telah dilaksanakan (reflect), pertemuan pertama dan kedua dikategorikan kurang karena hanya satu indikator yang terlaksana yaitu siswamelakukan refleksi tetapi indikator siswaaktif memberikan tanggapan terhadap sajian hasil pemecahan masalah tentang bangun datar segitiga dalam bentuk soal cerita dan siswamemperhatikan saran guru terhadap sajian hasil pemecahan masalah tentang bangun datar segitiga dalam bentuk soal cerita oleh kelompok lain tidak terlaksana.

Berdasarkan data dari siklus I dapat disimpulkan bahwa pencapaian implementasi aktivitas belajar matematika materi bangun datar melalui penerapan model pembelajaran pemecahan masalah (problem solving) untuk aspek siswa dikategorikan cukup. Untuk lebih jelasnya hasil observasi aktivitas belajar siswa dapat dilihat pada lampiran 5 halaman 83 dan lampiran 11 halaman 107.

\section{3) Hasil belajar}

Setelah pelaksanaan proses pembelajaran siklus I yang terdiri dari dua kali pertemuan, maka dilakukan tes hasil belajar. Adapun hasil analisis deskriptif terhadap skor pemerolehan skor hasil belajar siswa setelah diterapkannya model pembelajaran pemecahan masalah (problem solving) menunjukkan bahwa hasil belajar melalui model pembelajaran pemecahan masalah (problem solving) dengan subjek 28 orang siswa, memperoleh skor rata-rata kelas yaitu 64,28, skor tertinggi 100, skor terendah 25 .

Deskripsi distribusi frekuensi dan persentase ketuntasan hasil belajar matematika setelah diterapkan model pembelajaran pemecahan masalah (problem solving) pada siklus I dapat dilihat tabel 2 distribusi frekuensi dan persentase.

Tabel 2. Distribusi Frekuensi dan Presentasi

\begin{tabular}{lccc}
\hline Rentang Nilai & Kategori & Frekuensi & Presentase (\%) \\
\hline $0-69$ & Tidak Tuntas & 12 & $42 \%$ \\
\hline $70-100$ & Tuntas & 16 & $58 \%$ \\
\hline \multicolumn{2}{c}{ Jumlah } & 28 & $100 \%$ \\
\hline
\end{tabular}

Tabel tersebut menunjukkan bahwa pada subjek 28 orang siswa kelas V SDN Kakatua Kecamatan Mariso Kota Makassar terdapat 12 orang siswa (42\%) yang tidak tuntas hasil belajarnya dan 16 orang siswa $(58 \%)$ yang telah tuntas hasil belajarnya pada pembelajaran matematika. Hal ini berarti bahwa pada siklus I ketuntasan hasil belajar secara klasikal dalam pembelajaran matematika belum tercapai karena jumlah siswa yang hasil belajarnya tuntas kurang dari 
$70 \%$ yaitu $58 \%$ berarti masih terdapat $42 \%$ siswa yang diharapkan hasil belajarnya tuntas.

\section{Paparan Data Siklus II}

Pelaksanaan siklus II dimulai tanggal 03Oktober 2016 dan 10Oktober 2016 dengan materi bangun ruang kubus dan materi bangun ruang balok dalam bentuk soal cerita, yang kegiatan pelaksanaannya meliputi perencanaan, pelaksanaan, observasi, dan refleksi.

Pada saat proses pembelajaran berlangsung, observer/peneliti melakukan kegiatan pengamatan baik terhadap guru maupun siswa dengan hasil sebagai berikut:

\section{1) Hasil observasi aktivitas mengajar guru}

Lembar observasi kegiatan mengajar guru digunakan untuk mengetahui aktivitas mengajar guru pada pembelajaran matematika dengan menerapkan langkah-langkah model pembelajaran pemecahan masalah (problem solving). Pada setiap pertemuan observer mengamati dan memperhatikan guru dalam proses pembelajaran dengan menerapkan model pembelajaran pemecahan masalah (problem solving) yang terdiri atas 4 tahap yaitu (a) Memahami masalah sesuai dengan petunjuk (clue) yang diberikan; (b) Membuat rencana pemecahan masalah untuk memecahkan masalah; (c) Melaksanakan strategi pemecahan masalah (solve); (d) Memeriksa kembali penyelesaian yang telah dilaksanakan (reflect).

Berdasarkan hasil observasiaktivitas mengajar guru pada pertemuan pertama dan kedua, diperoleh data bahwa pada aspek guru memahami masalah sesuai dengan petunjuk yang diberikan dikategorikan cukup karena ketiga indikator terlaksana yaitu guru menjelaskan materi tentang bangun ruang kubus dan bangun ruang balok, guru memberikan masalah dalam bentuk LKS tentang bangun datar segitiga dalam bentuk soal cerita dan guru mempersilahkan siswa berdiskusi untuk menganalisis masalah tentang bangun ruang kubus dan bangun ruang balok dalam bentuk soal cerita yang terdapat dalam LKS.

Pada aspek membuat rencana pemecahan masalah untuk memecahkan masalah dikategorikan baik karena ketiga indikator terlaksana yaitu guru membimbing siswa menyusun pertanyaan pada soal cerita dalam bentuk kalimat matematika, guru mendorong siswa untuk mengemukakan ide dalam kelompoknya, dan guru membantu dan membimbing siswa saling bekerja sama dalam kelompok. Pada aspek melaksanakan strategi pemecahan masalah (solve), pertemuan pertama dan kedua dikategorikan cukup karena hanya dua indikator yang terlaksana yaitu guru mengarahkan siswa untuk menyelesaikan soal cerita tentang bangun ruang sesuai langkahlangkah dalam pemecahan masalah (problem solving) dan guru membantu siswa dalam memaparkan hasil diskusi kelompoknya sedangkan indikator guru meminta siswa untuk menuliskan hasil kerja kelompoknya di papan tulis dan kelompok lain memperhatikan tidak terlaksana. Pada aspek memeriksa kembali penyelesaian yang telah dilaksanakan (reflect), pertemuan pertama dan kedua dikategorikan baik karena ketiga indikator terlaksana yaitu guru membantu siswa untuk melakukan refleksi guru mendorong siswa untuk aktif memberikan tanggapan terhadap sajian hasil pemecahan masalah dalam bentuk soal cerita, dan guru memberikan saran terhadap sajian hasil pemecahan masalah tentang bangun ruang dalam bentuk soal cerita oleh kelompok lain

Berdasarkan data dari siklus II dapat disimpulkan bahwa pencapaian implementasi aktivitas belajar matematika materi bangun ruang melalui penerapan model pembelajaran pemecahan masalah (problem solving) untuk aspek guru dikategorikan baik.

\section{2) Hasil observasi aktivitas belajar siswa}

Lembar observasi kegiatan belajar siswa digunakan untuk mengetahui aktivitas belajar siswa pada pembelajaran matematika dengan menerapkan langkah-langkah model pembelajaran pemecahan masalah (problem solving). Pada setiap pertemuan observer mengamati dan memperhatikan siswa dalam proses pembelajaran dengan menerapkan pembelajaran pemecahan masalah yang terdiri atas 4 tahap yaitu (a) Memahami masalah sesuai dengan petunjuk (clue) yang diberikan; (b) Membuat rencana pemecahan masalah untuk memecahkan masalah; (c) Melaksanakan strategi pemecahan masalah (solve); (d) Memeriksa kembali penyelesaian yang telah dilaksanakan (reflect).

Berdasarkan observasi terhadap aktivitas belajar siswa, diperoleh data bahwa pada aspek memahami masalah sesuai dengan petunjuk (clue) yang diberikan, pertemuan pertama dan kedua dikategorikan baik karena ketiga indikator terlaksana yaitu siswa mendengarkan 
penjelasan dari guru tentang materi bangun ruang, siswa memahami masalah dalam bentuk LKS tentang bangun ruang dalam bentuk soal cerita, dan siswa berdiskusi untuk menganalisis masalah tentang bangun ruang dalam bentuk soal cerita yang terdapat dalam LKS. Pada aspek membuat rencana pemecahan masalah untuk memecahkan masalah, pertemuan pertama dan kedua dikategorikan baik karena ketiga indikator terlaksana yaitu siswa menyusun pertanyaan pada soal cerita tentang bangun ruang kubus dalam bentuk kalimat matematika, siswa mengemukakan ide dalam kelompoknya, dan siswa saling bekerja sama dalam kelompok. Pada aspek melaksanakan strategi pemecahan masalah (solve), pertemuan pertama dan kedua dikategorikan cukup karena hanya dua indikator yang terlaksana yaitu siswa mampu menyelesaikan soal cerita tentang bangun ruang sesuai langkah-langkah dalam pemecahan masalah (problem solving) dan siswa memaparkan hasil diskusi kelompoknya tapi indikator siswa menuliskan hasil kerja kelompoknya di papan tulis dan kelompok lain memperhatikan tidak terlaksana.

Pada aspek memeriksa kembali penyelesaian yang telah dilaksanakan (reflect), pertemuan pertama dan kedua dikategorikan baik karena ketiga indikator terlaksana yaitu siswa melakukan refleksi, siswa aktif memberikan tanggapan terhadap sajian hasil pemecahan masalah tentang bangun ruang kubus dalam bentuk soal cerita, dan siswa memperhatikan saran guru terhadap sajian hasil pemecahan masalah tentang bangun ruang kubus dalam bentuk soal cerita oleh kelompok lain

Berdasarkan data dari siklus II dapat disimpulkan bahwa pencapaian implementasi aktivitas belajar matematika materi bangun ruang melalui penerapan model pembelajaran pemecahan masalah (problem solving) untuk aspek siswa dikategorikan baik.

\section{3) Hasil belajar}

Setelah pelaksanaan proses pembelajaran siklus II yang terdiri dari dua kali pertemuan, maka dilakukan tes hasil belajar. Adapun hasil analisis deskriptif terhadap pemerolehan skor hasil belajar siswa setelah diterapkannya model pembelajaran pemecahan masalah (problem solving) menunjukkan bahwa hasil belajar murid melalui penerapan model pembelajaran pemecahan masalah (problem solving) dengan subjek 28 orang siswa, memperoleh skor rata-rata kelas yaitu 84,28 , skor tertinggi 100, skor terendah 40.

Deskripsi distribusi frekuensi dan presentase ketuntasan hasil belajar matematika setelah diterapkan model pembelajaran pemecahan masalah (problem solving) pada siklus II dapat dilihat pada 2 tabel distribusi frekuensi dan persentase.

Tabel 3. Distribusi Frekuensi dan Presentasi

\begin{tabular}{cccc}
\hline Rentang Nilai & Kategori & Frekuensi & Presentase (\%) \\
\hline $0-69$ & Tidak Tuntas & 6 & $21 \%$ \\
\hline $70-100$ & Tuntas & 22 & $79 \%$ \\
\hline \multicolumn{2}{c}{ Jumlah } & 28 & $100 \%$ \\
\hline
\end{tabular}

Tabel tersebut menunjukkan bahwa pada subjek 28 orang siswa kelas V SDN Kakatua Kecamatan Mariso Kota Makassar terdapat 6 orang siswa (21\%) yang tidak tuntas hasil belajarnya dan 22 orang siswa (79\%) yang telah tuntas hasil belajarnya pada pembelajaran matematika. Hal ini berarti bahwa pada siklus II ketuntasan hasil belajar secara klasikal dalam pembelajaran matematika sudah tercapai karena jumlah siswa yang hasil belajarnya tuntas lebih dari $70 \%$ yaitu $79 \%$.

\section{B. Pembahasan Hasil Penelitian}

Hasil belajar siswa yang diperoleh setelah dilaksanakan siklus I dalam pembelajaran matematika dengan pokok bahasan bangun datar dengan menerapkan model pembelajaran pemecahan masalah (problem solving), skor rata-rata yang diperoleh adalah 64,28 dengan nilai tetinggi 100 dan yang terendah 25 dari skor ideal 100, dan yang tuntas hasil belajarnya 16 orang siswa dan yang tidak tuntas hasil belajarnya 12 orang siswa. Ini disebabkan karena kurangnya motivasi belajar, kurangnya pengetahuan siswa dalam menyelesaikan soal cerita sehingga siswa tidak tertarik dengan mata pelajaran matematika yang diberikan walaupun guru memberi petunjuk dalam berkelompok, namun dalam mengerjakan tugas masih didominasi oleh siswa yang aktif (pintar) saja. Siswa yang lainnya hanya menonton dan bercerita saja, mereka tidak mau bekerja sama. Oleh karena 
itu setelah pembelajaran selesai, guru lebih banyak memberikan arahan dan bimbingan cara menyeleseikan soal cerita matematika.

Pada siklus II pelaksanaan pembelajaran tidak jauh berbeda dengan siklus I, hanya keaktifan siswa dalam pembelajaran sudah mulai nampak, dilihat dari keaktifan masingmasing kelompok dalam mengajukan pertanyaan, bekerja sama dalam menyelesaikan soal-soal yang diberikan oleh guru. Dilihat dari proses dan hasil belajar tes akhir yang telah dicapai, yaitu skor nilai ratarata tes akhir menunjukkan peningkatan pada siklus I yaitu 64,28 sedangkan siklus II nilai rata-rata skor adalah 84,28.

Keberhasilan Pelaksanaan dari siklus kesiklus dikarenakan guru dapat melaksanakan rancangan pembelajaran dengan baik sesuai dengan langkah-langkah dari penerapan model pembelajaran pemecahan masalah (problem solving). Dengan demikian meningkatnya hasil belajar siswa kelas V SDN Kakatua Kecamatan Mariso Kota Makassar karena adanya kerja sama yang baik dalam kelompok dan bimbingan serta arahan dari guru. Fakta yang membuktikan bahwa adanya penerapan model pembelajaran pemecahan masalah (problem solving) dapat meningkatkan hasil belajar metematika khususnya dalam menyelesaikan soal cerita matematika.

\section{KESIMPULAN \& SARAN}

Berdasarkan rumusan masalah, hasil temuan dan pemabahasan pada bab IV, maka hasil penelitian ini dapat disimpulkan bahwa: Model Pembelajaran Problem Solving dapat meningkatkan hasil belajar siswa kelas V SDN Kakatua Kecamatan Mariso Kota Makassar begitupun dengan aktivitas mengajar guru dan aktivitas belajar siswa dalam pembelajaran matematika dengan menerapkan model pembelajaran problem solving terjadi peningkatan secara signifikan berdasarkan atas beberapa aktivitas guru dan siswa yang telah diamati. Dengan nilai rata-rata hasil belajar matematika pada siklus I masuk pada kategori belum tuntas, selanjutnya pada siklus II nilai rata-rata hasil belajar siswa berada pada kategori tuntas yang diukur dengan menggunakan tes berbentuk soal cerita.

Sehubungan dengan kesimpulan penelitian di atas, maka diajukan saran sebagai berikut:

1. Kepala sekolah hendaknya selalu memberikan pembinaan dan pengawasan terhadap pelaksanaan tugas mengajar guru, di antaranya dalam penggunaan model pembelajaran.

2. Guru, hendaknya selalu menunjukkan keaktifan dalam proses pembelajaran seperti dalam memecahkan masalah matematika sebagai peningkatan kemampuan belajar siswa.

3. Guru hendaknya dalam mengajarkan materi pelajaran matematikaberupaya agar siswa dapat selalu aktif dalam proses pembelajaran dalambentuk kerjasama secara kelompok, seperti memecahkan masalah matematika dalam meningkatkan kemampuan belajar dan hasil belajar siswa.

4. Bagi peneliti yang ingin melakukan penelitian yang sama hendaknya hasil penelitian ini dapat dijadikan sebagai panduan, dimana kekurangan-kekurangan dan kelebihan-kelebihan yang terdapat pada penelitian ini dapat dijadikan sebagai bahan refleksi demi penyempurnaan penelitian di masa-masa berikutnya.

\section{DAFTAR PUSTAKA}

Akbar, Muhammad. 2015. Peningkatan Hasil Belajar Matematika dengan Penerapan Pendekatan Pemecahan Masalah (problem solving) di Kelas V SDN 17 Pare-pare. Skripsi. Makassar: Pendidikan Guru Sekolah Dasar Universitas Negeri Makassar.

Arikunto, Suharsini. 2008. Penelitian Tindakan Kelas. Jakarta: Bumi Aksara

Faturrahman, dkk. 2012. Pengantar Pendidikan. Jakarta: Prestasi Pustakarya

Hamzah. 2014. Perencanaan Strategi Pembelajaran Matematika. Jakarta: Raja Grafindo Persada.

Huda, Miftahul. 2013. Model-model Pengajaran dan Pembelajaran. Malang. Pustaka Pelajar

Kunandar. 2012. Langkah Mudah Penelitian Tindakan Kelas Sebagai Pengembangan Profesi Guru. Jakarta: Rajawali Pers

Mulyasa. 2012. Praktik Penelitian Tindakan Kelas. Bandung: Remaja Rosdakarya.

Riyanto, Yatim. 2009. Paradigma Baru Pembelajaran. Jakarta: Kencana Prenadamedia Group

Runtukahu, Tombokan \& Kandou, Selpius. 2013. Pembelajaran Matematika Dasar Bagi Anak Berkesulitan Belajar. Yogyakarta: Ar-Ruzz Media

Shoimin, Aris. 2014. 68 Model Pembelajaran Inovatif dalam Kurikulum 2013. Jakarta: Ar-Ruzz Media 
Suprijono, Agus. 2012. Cooperative learning Teori dan Aplikasi PAIKEM. Yogyakarta: Pustaka Pelajar

Susanto, Ahmad. 2014. Teori Belajar dan Pembelajaran di Sekolah Dasar. Jakarta: Kencana Prenadamedia Group

Soedjadi. 2000. Kiat Pendidikan Matematika di Indonesia. Jakarta: Direktorat Jendral Pendidikan Tinggi Departemen Pendidikan Nasional

Suyadi. 2013. Panduan Penelitian Tindakan Kelas. Jogjakarta: DIVA Press

Tirtarahardja, Umar. Dkk,. 2008. Pengantar Pendidikan. Jakarta: Rineka Cipta

Wardhani, Sri. Dkk,. 2010. Pembelajaran Kemampuan Pemecahan Masalah Matematika di SD. Yogyakarta: Pusat Pengembangan dan Pemberdayaan Pendidik dan Tenaga Kependidikan (PPPPTK) Matematika 